\title{
PERKEMBANGAN PENGATURAN OBJEK WAKAF DALAM PERSPEKTIF HUKUM TANAH NASIONAL DAN HUKUM ISLAM
}

\section{FX. SUMARJA}

Dosen Fakultas Hukum Universitas Lampung Jalan Prof. Dr. Ir. Soemantri Brojonegoro No. 1 Gedung Meneng Bandar Lampung 35145, Email: fxsmj.unila@gmail.com

\begin{abstract}
ABSTRAK
Penelitian ini bertujuan: pertama, menganalisis perkembangan pengaturan objek wakaf dalam perspektif Hukum Tanah Nasional dan Hukum Islam; kedua menganalisis status ketentuan wakaf tanah dalam Undang-Undang Pokok Agraria dengan lahirnya Undang-Undang Wakaf. Penelitian dilakukan secara normatif. Bahan hukumnya Hukum Tanah Nasinoal dan Hukum Islam. Analisis data menggunakan analisis hukum (law analisys) atau rechtmatigheidsdaad tootsing. Hasil penelitian ditemukan bahwa objek wakaf mengalami perluasan. Wakaf benda bergerak dan benda tidak bergerak. Benda tidak bergerak mencakup tanah milik dan yang lain, seperti Hak Guna Usaha, Hak Guna Bangunan dan Hak Pakai. Perkembangan objek wakaf dipengaruhi oleh perkembangan paham atau ajaran yang dianut oleh masyarakat. Wakaf tidak harus mengekalkan manfaat benda wakaf. Undang-Undang Wakaf menyebabkan konflik hukum antara ketentuan wakaf dalam Undang-Undang Pokok Agraria dengan Undang-Undang Wakaf. Peraturan Pemerintah tentang Pendaftaran Tanah Milik dengan Peraturan Pemerintah tentang Pelaksanaan Undang-Undang Wakaf. Ketentuan wakaf dalam Undang-Undang Pokok Agraria tetap berlaku berdasarkan asas lex specialis derogat legi generalis. Berdasarkan asas lex posterior derogat legi priori yang berlaku adalah Peraturan Pemerintah tentang Pelaksanaan UndangUndang Wakaf.
\end{abstract}

Kata kunci: Perkembangan, Wakaf, Hukum Tanah Nasional, Hukum Islam.

\begin{abstract}
This study aims: first, to analyze the development of objects arrangement waqf in perspective National Land Law and the Law of Islam; secondly, analyze the status of waqf land of the provisions in the Basic Agrarian Law with the birth of Waqf Act. Research conducted normative. Materials ruling National Land Law and the Law of Islam. Analysis of the data using analysis of law or rechtmatigheidsdaad tootsing. The research found that the object of waqf expanded. Waqts movable and immovable objects. Includes fixtures and other property, such as leasehold, Broking and Right to Use. The development of waqf objects influenced by the development ideology or doctrine held by the public. Waqts do not have to perpetuate the benefits of charitable objects. Act waqt cause legal conflicts between the provisions of waqts in the Basic Agrarian Law to the Waqf Act. Government Regulations on Land Registration Owned by Government Regulation Implementation Waqts Act. Terms of waqts in the Basic Agrarian Law remains in effect based on the principle of lex specialis derogat legi generalis. Based on the principle of lex posterior derogat legi priori the applicable Regulation on the Implementation of the Law of Waqts.
\end{abstract}

Keyword: Development, Waqts, National Land Law, Law of Islam. 


\section{PENDAHULUAN}

Hukum Tanah Nasional (HTN) adalah peraturan perundang-undangan yang mengatur hak-hak penguasaan atas tanah dan aturan pelaksanaannya. HTN dituangkan di dalam Undang-Undang No. 5 Tahun 1960 tentang Peraturan Dasar Pokok-Pokok Agraria (UUPA) dan aturan pelaksanaannya. Secara normatif perwakafan tanah pertama kali di Indonesia diatur dalam Pasal 49 ayat (3) UUPA. Wakaf tanah hak milik mendapatkan pengaturan lebih lanjut setelah beberapa tahun kemudian. Pemerintah mengeluarkan Peraturan Pemerintah No. 28 Tahun 1977 tentang Perwakafan Tanah Milik (PP Perwakafan Tanah Milik) dan Peraturan Menteri Dalam Negeri No. 6 Tahun 1977. Pada tahun 2004 Pemerintah mengeluarkan UndangUndang No. 41 Tahun 2004 tentang Wakaf (Undang-Undang Wakaf). UndangUndang Wakaf dilaksanakan lebih lanjut dengan Peraturan Pemerintah No. 42 Tahun 2006 tentang Pelaksanaan Undang-Undang Wakaf (PP Pelaksanaan Undang-undang Wakaf). Dua peraturan perundang-undangan terakhir tidak hanya mengatur wakaf tanah, tetapi lebih luas dari itu objeknya. Tanah yang diwakafkan tidak terbatas hak milik seperti yang diatur di dalam UUPA, misalnya Hak Guna Bangunan (HGB) atau Hak Pakai. 


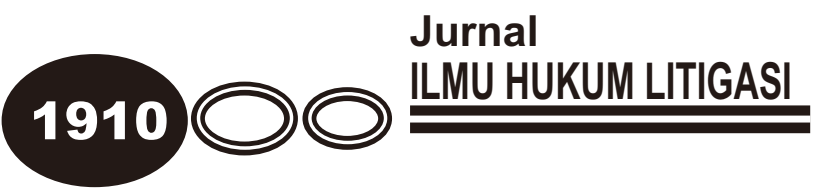

Hukum merupakan sistem terbuka yang bersifat konsisten. Hukum sebagai sistem berarti merupakan tatanan suatu kesatuan yang utuh terdiri dari bagian-bagian atau unsur-unsur yang saling berkaitan erat satu sama lain dan tidak menginginkan terjadinya konflik (Sudikno, 2011: 51-55). Hukum sebagai sistem terbuka merupakan tatanan (peraturan) yang dipengaruhi oleh faktor-faktor kebudayaan, sosial, ekonomi, sejarah dan sebagainya temasuk keyakinan masyarakat. Oleh karenanya hukum mengalami perkembangan. Dalam sistem hukum yang mengalami perkembangan tidak dikehendaki terjadinya konflik atau pertentangan di dalamnya, dan kalau terjadi konflik tidak akan dibiarkan berlarutlarut. Cara mengatasi konflik diperlukan adanya suatu ketentuan umum berupa asas-asas yang pelaksanaanya konsisten, yaitu asas lex specialis derogat lege generali, lex superior derogat legi inferiori, lex posterior derogat legi priori. Menurut Bernard Arief Sidharta (dalam Susi Dwi Harjanti, 2011: 9) diperlukan collisie-regels untuk menjaga keutuhan tata hukum.

Berdasarkan uraian di atas permasalahan yang dikemukakan di sini adalah:

1. Apakah perkembangan objek wakaf telah sesuai dengan dasar-dasar/ prinsip Hukum Islam? 
2. Bagaimanakah status ketentuan wakaf tanah yang ada di dalam UUPA dan aturan pelaksanaannya dengan lahirnya Undang-undang Wakaf?

\section{METODE PENELITIAN}

Spesifikasi penelitian ini termasuk penelitian hukum normatif. Penelitian hukum normatif dimaksudkan untuk melihat hukum sebagai suatu sistem peraturan-peraturan yang abstrak, termasuk asas-asas dan konsepsi-konsepsinya. Peraturan sebagai sesuatu yang berdiri sendiri atau lembaga otonom yang terlepas dari kaitan-kaitannya dengan hal-hal di luar peraturan-peraturan tersebut (Satjipto, 2006: 6).

Materi dan lokasi penelitian berupa hukum tanah nasional dan hukum Islam di Indonesia. Materi atau bahan hukum tersebut mencakup peraturanperaturan, buku-buku dan hasil kegiatan ilmiah yang terkait dengan wakaf tanah, yaitu: UUPA, Undang-Undang Wakaf, PP Perwakafan Tanah Milik, PP Pelaksanaan Undang-Undang Wakaf, buku-buku, dan makalah-makalah ilmiah.

Pengumpulan data dilakukan dengan penelusuran pustaka dan internet. 


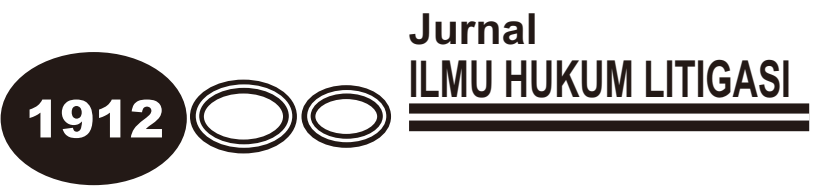

Pengolahan data dilakukan dengan cara membaca dan mengutip bagianbagian yang menjadi bahan kajian, serta dilakukan klasifikasi dan sistematisasi data. Data yang telah tersistematisasi dianalisis. Analisis data menggunakan analisis hukum (law analisys) atau rechtmatig-heidsdaad tootsing.

\section{HASIL PENELITIAN DAN ANALISIS}

\section{A. Perkembangan Pengaturan Objek Wakaf}

Sebelum membahas pokok permasalahan akan dibahas istilah "perspektif". Pertama, kata "perspektif" secara leksikal dalam Kamus Besar Bahasa Indonesia diartikan sebagai: 1) cara melukiskan suatu benda pada permukaan yang mendatar sebagaimana yang terlihat oleh mata dengan tiga dimensi (panjang, lebar, dan tinggi); dan 2) sudut pandang atau pandangan (KKB, 2001: 864). Kedua, kata "hukum" diartikan sebagai: 1) peraturan atau adat yang secara resmi dianggap mengikat, yang dikukuhkan oleh penguasa atau pemerintah; 2) undang-undang, peraturan, dan sebagainya, untuk mengatur pergaulan hidup masyarakat; 3) patokan (kaidah, ketentuan) mengenai peristiwa (alam dan sebagainya) yang tertentu; 4) pertimbangan yang ditetapkan oleh hakim (di pengadilan) atau vonis (KBBI, 2001 : 410). Jika dirangkaikan kata "perspektif" dengan " perkembangan wakaf, Hukum 
Tata Negara (HTN) dan Hukum Islam" menjadi sebuah frase “perkembangan wakaf dalam perspektif HTN dan hukum Islam" yang berarti “perkembangan wakaf dilihat dari sudut pandang ketentuan HTN dan Hukum Islam".

Menurut Nur Kholis walaupun pemerintah telah membuat aturan terkait dengan wakaf, yaitu UUPA dan PP Perwakafan Tanah Milik, akan tetapi peraturan ini hanya mengatur wakaf pertanahan saja. Ini berarti tidak jauh berbeda dengan model wakaf pada periode awal, yang identik dengan wakaf tanah. Kegunaan wakaf terbatas pada kegiatan sosial keagamaan, seperti masjid, kuburan, madrasah, dan lain-lain (Nur, 2009: 9).

Minimnya regulasi yang mengatur perwakafan, berdampak pada perkembangan wakaf di Indonesia. Perkembangan wakaf mengalami stagnasi. Stagnasi perkembangan wakaf di Indonesia mulai mengalami dinamisasi ketika tahun 2001, beberapa praktisi ekonomi Islam mulai mengusung paradigma baru ke tengah masyarakat. Mereka mengemukakan konsep baru pengelolaan wakaf tunai untuk peningkatan kesejahteraan umat. Konsep tersebut menarik dan mampu memberikan energi untuk menggerakkan kemandegan wakaf. Pada tahun 2002, Majelis Ulama Indonesia (MUI) menyambut baik konsep 


\section{4 \\ Jurnal}

tersebut dengan mengeluarkan fatwa yang membolehkan wakaf uang (waqf al-nuqud) (Nur, 2009: 10).

Konsekuensi fatwa MUI tersebut diikuti oleh Pemerintah dengan melahirkan Undang-Undang Wakaf. Wakaf meliputi benda tidak bergerak dan benda bergerak termasuk uang. Undang-Undang Wakaf mengatur kebijakan perwakafan mulai dari pembentukan nazhir, badan wakaf sampai dengan pengelolaan harta wakaf. Undang-Undang Wakaf memerlukan perangkat lain untuk dapat menjalankan fungsinya. Perangkat lain itu mencakup Peraturan Pemerintah, Peraturan Menteri Agama tentang Wakaf Uang dan Badan Wakaf Indonesia (BWI). Perangkat peraturan akan menjadi juklak dalam implementasi wakaf. Badan Wakaf Indonesia (BWI) akan berfungsi sebagai sentral nazhir wakaf.

Setelah melalui proses panjang, pada penghujung tahun 2006 terbitlah PP Pelaksanaan Undang-Undang Wakaf. Setelah itu, pada Juli 2007 keluar Keputusan Presiden Republik Indonesia Nomor 75/M tahun 2007 yang memutuskan dan mengangkat keanggotaan BWI periode 2007-2010. Terakhir kepengurusan BWI ditetapkan dengan Keputusan Presiden Nomor 111/M tahun 2011 tertanggal 9 Juni 2011, untuk masa bakti 2011-2014. 
Berdasarkan realitas seperti diuraikan di atas, perkembangan konsep wakaf di Indonesia tidak datang tiba-tiba namun melalui proses panjang. Secara normatif konsep awal wakaf yang dianut adalah konsep wakaf untuk benda tidak bergerak dan harus untuk selamanya. Pada perkembangannya konsep wakaf berubah menjadi wakaf untuk jangka waktu tertentu (wakaf tidak harus selamanya). Hal ini dapat dipahami karena dari awalpun terdapat perbedaan pendapat tentang pengertian atau konsep wakaf. Pengertian/konsep wakaf yang dianut oleh masyarakat (umat muslim) akan berdampak pada hukum yang berlaku.

Menurut Cholil Nafis Wakil Sekretaris Badan Wakaf Indonesia, "Rethinking Fiqih Wakaf" (http://bwi.or.id), secara etimologi wakaf berasal dari perkataan Arab "Waqf" yang berarti "al-Habs". la merupakan kata yang berbentuk masdar (infinitive noun) yang pada dasarnya berarti menahan, berhenti, atau diam. Apabila kata tersebut dihubungkan dengan harta seperti tanah, binatang dan yang lain, ia berarti pembekuan hak milik untuk faedah tertentu. Sebagai satu istilah dalam syariah Islam, wakaf diartikan sebagai penahanan hak milik atas materi benda (al-`ain) untuk tujuan menyedekahkan manfaat atau faedahnya (al-manfa'ah). Terdapat empat pendapat tentang 


\section{Jurnal

wakaf yang membawa akibat berbeda pada hukum yang ditimbulkan, yaitu Imam Hanafi, Maliki, Syafi'i, dan Hambali (Nur, 2009: 3):

a. Imam Hanafi, wakaf adalah menahan materi benda (al-'ain) milik Wakif dan menyedekahkan manfaatnya kepada siapapun yang diinginkan untuk tujuan kebajikan. Pengertian wakaf tersebut menjelaskan bahwa kedudukan harta wakaf masih tetap tertahan atau terhenti di tangan Wakif itu sendiri. Dengan artian, Wakif masih menjadi pemilik harta yang diwakafkannya, manakala perwakafan hanya terjadi di atas manfaat harta tersebut, bukan termasuk aset hartanya.

b. Imam Maliki, wakaf adalah menjadikan manfaat suatu harta yang dimiliki (walaupun pemilikannya dengan cara sewa) untuk diberikan kepada orang yang berhak dengan satu akad (shighat) dalam jangka waktu tertentu sesuai dengan keinginan Wakif. Pengertian wakaf tersebut hanya menentukan pemberian wakaf kepada orang atau tempat yang berhak saja.

c. Imam Syafi'i, wakaf adalah menahan harta yang bisa memberi manfaat serta kekal materi bendanya (al-'ain) dengan cara memutuskan hak pengelolaan yang dimiliki oleh Wakif untuk diserahkan kepada Nazhir yang dibolehkan oleh syariah. Golongan ini mensyaratkan harta yang 
diwakafkan harus harta yang kekal materi bendanya (al-'ain). Harta kekal diartikan harta yang tidak mudah rusak atau musnah serta dapat diambil manfaatnya secara terus menerus.

d. Imam Hambali, wakaf adalah menahan asal harta (tanah) dan menyedekahkan manfaat yang dihasilkan.

Jika diperhatikan empat pendapat ulama di atas dikaitkan dengan peraturan di bidang wakaf di Indonesia, maka dapat diketahui bahwa Kompilasi Hukum Islam, UUPA dan PP Perwakafan Tanah Milik dengan tegas menganut faham Imam Syafi'i. Wakaf diartikan sebagai perbuatan orang atau badan hukum yang memisahkan sebagian dari benda miliknya dan melembagakannya untuk selama-lamanya guna kepentingan ibadah atau keperluan umum lainnya sesuai dengan ajaran Islam (Yulia, 2004: 25). Undang-Undang Wakaf tidak menganut sepenuhnya pendapat Imam Syafi'i. Menurut Nur Kholis (2009:4) Undang-Undang Wakaf mengadopsi seluruh pendapat ulama, sehingga pengertian wakaf menjadi lebih luas dan lebih komplit. Wakaf diartikan dengan perbuatan hukum Wakif untuk memisahkan dan/atau menyerahkan sebagian harta benda miliknya untuk dimanfaatkan selamanya atau untuk jangka waktu tertentu sesuai dengan kepentingannya guna keperluan ibadah dan / atau kesejahteraan umum menurut syariah. 


\section{Jurnal \\ 1918 \\ ILMU HUKUM LITIGASI}

Pengertian ini sama dengan pengertian wakaf yang diatur di dalam penjelasan Pasal 49 huruf e Undang-Undang No. 3 Tahun 2006 Perubahan Atas Undang-Undang No. 7 Tahun 1989 tentang Peradilan Agama. Pengertian wakaf menurut penjelasan undang-undang yang dimaksud terakhir adalah perbuatan seseorang atau sekelompok orang (wakif) untuk memisahkan dan/atau menyerahkan sebagian harta benda miliknya untuk dimanfaatkan selamanya atau untuk jangka waktu tertentu sesuai dengan kepentingannya guna keperluan ibadah dan/atau kesejahteraan umum menurut syari'ah.

Berdasarkan beberapa pengertian wakaf tersebut, dapat dinyatakan bahwa wakaf bertujuan untuk memberikan manfaat atau faedah harta yang diwakafkan kepada orang yang berhak dan dipergunakan sesuai dengan ajaran syariah Islam. Hal ini sesuai dengan fungsi wakaf yang disebutkan Pasal 5 Undang-Undang Wakaf yang menyatakan wakaf berfungsi untuk mewujudkan potensi dan manfaat ekonomis harta benda wakaf untuk kepentingan ibadah dan untuk memajukan kesejahteraan umum.

Paham wakaf dan tujuan wakaf, baik yang dianut UUPA maupun Kompilasi Hukum Islam dianggap menghambat perkembangan perwakafan di tanah air. Kedua ketentuan tersebut membatasi benda yang dapat diwakafkan yaitu tanah hak milik. Undang-Undang Wakaf membuka peluang yang cukup 
luas bagi masyarakat (umat muslim) untuk dapat mewakafkan selain tanah hak milik, baik yang sudah terdaftar maupun yang belum terdaftar. Tanah hak yang dapat diwakafkan adalah, Hak Milik (HM); Hak Guna Usaha (HGU), Hak Guna Bangunan (HGB) atau Hak Pakai di atas tanah negara; HGB atau Hak Pakai di atas Hak Pengelolaan atau Hak Milik, dan wajib mendapat izin tertulis dari pemegang Hak Pengelolaan atau Hak Milik; serta hak milik atas satuan rumah susun. Wakaf bisa juga benda bergerak, termasuk uang.

Objek wakaf yang berwujud tanah di dalam Undang-Undang Wakaf, seharusnya termasuk pula hak atas tanah yang diatur pada Pasal 44 dan Pasal 53 ayat (1) UUPA. Pasal 44 UUPA mengatur Hak Sewa Untuk Bangunan. Pasal 53 ayat (1) UUPA mengatur hak atas tanah yang bersifat sementara, yaitu Gadai Tanah, Sewa Tanah Pertanian, dan Bagi Hasil Tanah Pertanian. Hak sewa untuk bangunan dan hak-hak atas tanah yang bersifat sementara juga mengandung hak atau sesuatu yang bernilai ekonomis dan dapat dimanfaatkan untuk kesejahteraan umum. Hal ini sekaligus dapat menguatkan pendapat, bahwa paham wakaf yang dianut akan menentukan hukum yang berlaku atau ditimbulkan. Wakaf yang tidak harus mengekalkan manfaat benda wakaf untuk tanah bisa hak atas tanah, selain hak milik. 


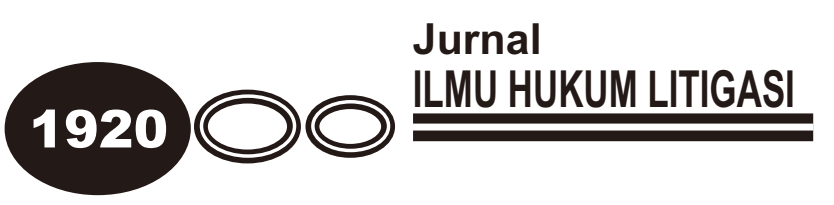

Berdasarkan ketentuan yang ada bahwa telah terjadi perubahan atau tepatnya perluasan objek wakaf yang tidak hanya benda tidak bergerak tetapi juga benda bergerak. Semula objek wakaf terbatas benda tidak bergerak yang berwujud tanah hak milik. Konsekuensi perubahan objek wakaf adalah perubahan yang lain, yaitu lembaga Pejabat Pembuat Akta Ikrar Wakaf (PPAIW). Lembaga PPAIW menurut Undang-Undang Wakaf dan PP Pelaksanaan Undang-Undang Wakaf juga ikut bertambah. Terdapat PPAIW yang diberikan kewenangan untuk membuatkan akta ikrar wakaf benda tidak bergerak dan PPAIW yang diberikan kewenangan untuk membuatkan akta ikrar wakaf benda bergerak. Bahkan, seorang notaris yang telah memenuhi persyaratan tertentu dapat juga diangkat sebagai PPAIW. Artinya, UndangUndang Wakaf membuka formasi/jabatan baru di bidang pembuatan akta ikrar wakaf.

Selain objek wakaf dan PPAIW yang mengalami perluasan adalah unsur wakaf dan isi akta ikrar wakaf. Semula unsur wakaf hanya ada empat, yaitu: 1) Wakif, 2) Nazhir, 3) benda yang diwakafkan, 4) ikrar wakaf. Sekarang unsur wakaf ada enam, terdapat tambahan dua unsur yaitu peruntukan benda wakaf dan jangka waktu wakaf. Isi akta ikrar wakaf menurut Undang-Undang Wakaf minimal memuat paling sedikit mencakup: 
a. nama dan identitas Wakif; b. nama dan identitas Nazhir; c. data dan keterangan harta benda wakaf; d. peruntukan harta benda wakaf; dan e. jangka waktu wakaf. Berdasarkan ketentuan PP Pelaksanaan Undang-Undang Wakaf isi akta ikrar wakaf bertambah yaitu Mauquf alaih. Mauquf alaih adalah pihak yang ditunjuk untuk memperoleh manfaat dari peruntukan harta benda wakaf sesuai pernyataan kehendak Wakif yang dituangkan dalam Akta Ikrar Wakaf.

Perubahan-perubahan yang telah diuraikan di atas tentunya mengakibatkan perubahan yang lain. Perubahan itu akan mencakup tata cara perwakafan, pendaftaran wakaf, pelaporan wakaf, termasuk lembaga yang menangani wakaf. Mengenai hal-hal tersebut tidak akan dibahas pada kesempatan ini.

B. Status Ketentuan Wakaf dalam UUPA dan Aturan Pelaksanaannya

Undang-Undang Wakaf akan menimbulkan pertanyaan hukum bagaimana kedudukan ketentuan wakaf di dalam UUPA dengan lahirnya Undang-Undang Wakaf. Guna mengetahui jawaban atas persoalan itu perlu memahami isi ketentuan wakaf di dalam UUPA, latar belakang pengaturannya, dan asas-asas hukum yang berlaku. Pasal 49 ayat (3) UUPA mengatur, bahwa: perwakafan tanah milik dilindungi dan diatur dengan 


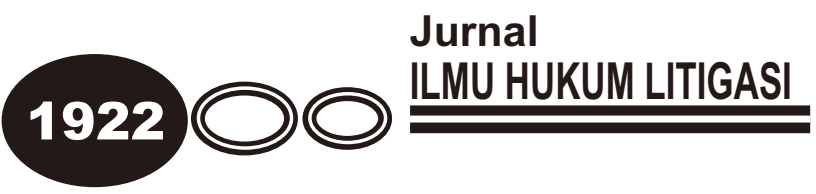

Peraturan Pemerintah. Pasal ini memberikan tempat yang khusus bagi hak-hak yang bersangkutan dengan kegiatan keagamaan.

UUPA memerintahkan perwakafan hak milik dilindungi dan diatur dengan peraturan pemerintah. Ketentuan ini bukan berarti yang dilindungi hanya perwakafan hak milik, perwakafan yang lainpun tetap harus dilindungi. Apalagi telah ditegaskan di dalam penjelasan UUPA bahwa soal-soal yang bersangkutan dengan peribadatan dan keperluan-keperluan suci lainnya, dalam hukum agraria yang baru akan mendapat perhatian sebagaimana mestinya. Hal ini mendapat penegasan dalam Pasal 58 ayat (1) RUU Pertanahan (tanggal 27 Maret 2013), bahwa "Perwakafan Tanah dan lembaga yang sejenis menurut ajaran agama yang dianut masyarakat Indonesia, dilindungi keberadaannya". Artinya perwakafan hak-hak atas tanah selain hak milik juga tetap harus mendapatkan perhatian. Kehadiran UndangUndang Wakaf tidak serta merta meniadakan ketentuan wakaf dalam UUPA.

Cara hapusnya hak milik atas tanah menurut Pasal 27 UUPA adalah tanah jatuh kepada negara dan tanahnya musnah. Tanah jatuh pada negara dikarenakan: pencabutan hak berdasarkan Pasal 18, penyerahan dengan sukarela oleh pemilik-nya, diterlantarkan, dan karena ketentuan Pasal 21 ayat (3) dan 26 ayat (2). UUPA tidak mengatur hapusnya hak atas tanah karena 
diwakafkan, demikian juga yang ditentukan dalam Pasal 40 RUU Pertanahan (tanggal 27 Maret 2013). Secara normatif hak atas tanah akan hapus kalau jatuh kepada negara seperti yang termuat pada Pasal 27 UUPA. Secara teoritis tanah hak yang diwakafkan akan berubah menjadi tanah wakaf, berarti hak atas tanahnya hapus. Pandangan ini dapat dibenarkan jika secara teoritis wakaf yang dianut adalah paham Syafi'i. Meskipun UUPA menganut paham Syafi'i, namun UUPA tidak menganut sepenuhnya terutama terkait hapusnya hak atas tanah. Kalau UUPA mau konsekuen menganut paham Syafi'i, mestinya salah satu cara hapusnya hak milik atas tanah adalah karena tanah diwakafkan. Tetapi ternyata konsep atau paham Syafi'i ini tidak diikuti sepenuhnya oleh UUPA, sehingga tidak ada pengaturan dalam Pasal 27 UUPA yang berbunyi hapusnya hak milik karena diwakafkan. Hal ini dapat dipahami karena pembentuk UUPA ternyata telah berpikir jauh ke depan terkait dengan perkembangan perwakafan tanah di Indonesia. Wakaf tidak harus tanah hak milik. Pemikiran ini dapat terbaca di dalam ketentuan Pasal 27 dan penjelasan Pasal 49 UUPA. 


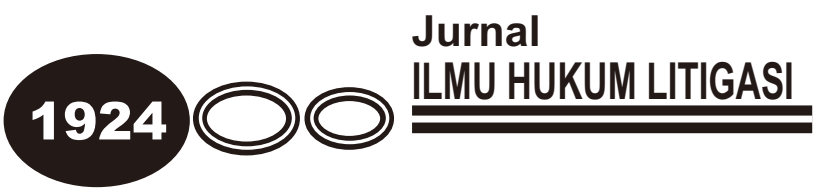

Parlindungan, AP (2008), berpendapat bahwa tanah yang diwakafkan tidak berakhir hak atas tanahnya. Bahasan dalam bukunya yang berjudul "Berakhirnya Hak-Hak Atas Tanah Menurut Sistem UUPA" tidak menguraikan berakhirnya hak atas tanah karena diwakafkan. Dengan demikian perbuatan wakaf tidak menyebabkan hapusnya hak, tetapi subjek haknya yang berpindah dan jenis haknya yang berubah dari hak milik individual menjadi tanah wakaf. Berbeda dengan Boedi Harsono (2008: 344-345), hak atas tanah hapus karena tanah diwakafkan. Tetapi tanahnya tidak menjadi tanah negara melainkan memperoleh status yang khusus sebagai tanah wakaf, yang diatur oleh Hukum Agama Islam. Pandangan Boedi Harsono dapat dipahami, karena beliau berangkat dari tujuan wakaf, yaitu mengekalkan manfaat tanah wakaf.

UUPA memerintahkan pengaturan perwakafan tanah hak milik dengan peraturan pemerintah. Peraturan pemerintah yang dimaksudkan adalah PP No. 28 Tahun 1977 tentang Pendaftaran Tanah Milik. Pada waktu itu tidak ada pengaturan yang tuntas dalam bentuk peraturan perundangundangan. Keadaan tersebut memudahkan terjadinya penyimpangan dari hakikat dan tujuan wakaf sendiri. Terutama karena terdapatnya beraneka ragam bentuk perwakafan, seperti wakaf keluarga, wakaf umum atau wakaf 
sosial dan lain-lainnya. Mendaftarkan benda yang diwakafkan tidak menjadi keharusan, sehingga banyak tanah wakaf yang tidak diketahui keberadaannya. Dampaknya benda-benda yang diwakafkan termasuk tanah, dalam perkembangannya kemudian dianggap sebagai milik para ahli waris Nazhir(pengurus)-nya (Boedi, 2008: 345).

Mengingat adanya perkembangan hukum wakaf, yaitu wakaf tanah tidak hanya hak milik tetapi bisa juga hak atas tanah yang lain. Tata cara perwakafan tanah hak milik diatur di dalam PP Pendaftaran Tanah Milik. Sementara itu telah lahir peraturan pemerintah yang baru yang mengatur tatacara perwakafan secara umum, yaitu PP No. 42 Tahun 2006 tentang Pelaksanaan Undang-Undang Wakaf. Mengingat PP Pelaksanaan UndangUndang Wakaf telah mengatur juga tata cara perwakafan tanah hak termasuk tanah hak milik, maka PP Pendaftaran Tanah Milik menjadi tidak berlaku lagi.

Persoalan hukum tersebut di atas dapat juga diatasi dengan menggunakan asas-asas hukum yang ada. Perbedaan antara UUPA dan Undang-Undang Wakaf dapat diselesaikan dengan menggunakan asas hukum lex specialis derogat legi generalis. Asas hukum ini berkaitan dengan persyaratan kerberlakuan yuridis peraturan perundang-undangan, atau yang oleh Bruggink disebut keberlakuan normatif atau keberlakuan formal. 


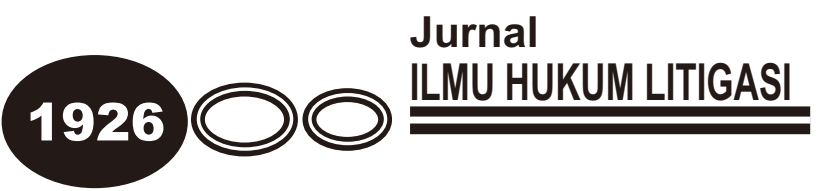

Keberlakuan normatif atau formal adalah jika kaidah hukum khusus yang lebih rendah diderivasi dari kaidah hukum umum yang lebih tinggi (Bruggink, 1999: 150). Keberlakuan yuridis atau normatif tersebut pada dasarnya merupakan konsekuensi dari dianutnya teori tata susunan atau hirarki perundang-undangan (stufenbautheorie) dari Hans Kelsen dan teori susunan norma hukum negara dari Hans Nawiasky.

Norma hukum itu berjenjang-jenjang dan berlapis-lapis dalam suatu hierarki (tata susunan), demikian menurut Stufenbautheorie. Suatu norma yang lebih rendah berlaku, bersumber dan berdasar pada norma yang lebih tinggi, norma yang lebih tinggi berlaku, bersumber dan berdasar pada norma yang lebih tinggi lagi, demikian seterusnya sampai pada suatu norma yang tidak dapat ditelusuri lebih lanjut dan bersifat hipotesis dan fiktif yaitu Norma Dasar (Grundnorm) (Kelsen, 2010: 113; 2010a: 244-245). Teori ini dikembangkan lebih lanjut oleh Hans Nawiasky, yang kemudian disebut sebagai tata susunan norma hukum negara. Hans Nawiasky mengelompokkan norma hukum dalam suatu negara menjadi empat kelompok besar, yaitu: staatsfundamentalnorm (norma fundamental negara), staatsgrundgesetz (aturan dasar negara/aturan pokok negara), formellgesetz (undang-undang formal), dan 
verordnung \& autonome statzung (aturan pelaksana dan aturan otonom) (Maria, 2007: 45).

Menurut Bernard Arief Sidharta (dalam Susi, Dwi Harjanti, 2011: 9), sehubungan dengan penataan hierarki-kal, muncul sejumlah aturan kolisi (collisieregels) untuk mempertahankan keutuhan tata-hukum, yaitu asas lex specialis derogat lege generali, asas lex superior derogat legi inferiori, asas lex posterior derogat legi priori, dan asas non-retroaktif. Dalam mengatasi konflik hukum pegangan dasarnya adalah rasio hukum dan asas-asas hukum. IImu hukum menyediakan asas-asas hukum penyelesaian konflik, yaitu: 1) Asas lex posterior derogat legi priori: undang-undang yang kemudian mengalahkan yang terdahulu; 2) Asas lex specialis derogat legi generali: undang-undang yang khusus mengalahkan yang umum; 3) Asas lex superior derogat legi inferior: undang-undang yang lebih tinggi mengalahkan yang lebih rendah.

Berdasarkan persyaratan keberlakuan yuridis atau normatif atau formal, serta teori stufenbau dan tata susunan norma hukum di atas, maka ketentuan wakaf yang berlaku adalah dua-duanya, yaitu UUPA dan UndangUndang Wakaf. Permasalahannya, lingkup benda wakaf kedua undangundang ini berbeda. Asas hukum lex posterior derogat legi priori tidak dapat digunakan, karena keduanya mengatur objek yang tidak sama. Jika merujuk 


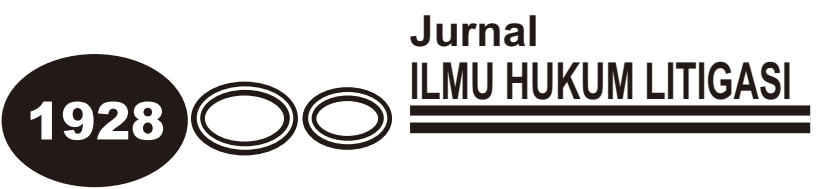

asas hukum lex posterior derogat lege priori, maka lingkup wakaf yang menjadi objek wakaf idealnya menggunakan ketentuan Undang-Undang Wakaf, yang meliputi: tanah hak dan/atau benda tidak bergerak lainnya, dan benda bergerak termasuk uang. Hanya saja untuk menghindari beragam penafsiran sebaiknya dilakukan proses harmonisasi hukum melalui revisi UUPA. Terminologi yang dipakai dalam undang-undang yang baru seharusnya objek wakaf menjadi "tanah hak".

Lex specialis derogat legi generali adalah tepat untuk mengatasi persoalan hukum antara ketentuan wakaf dalam UUPA dan Undang-Undang Wakaf. Asas ini mengandung makna bahwa aturan hukum khusus akan mengesampingkan aturan hukum yang umum. Bagir Manan (2004: 57-58) memberikan contoh klasik hubungan antara ketentuan dalam KUHPerdata (BW) dengan KUHDagang (WvK). Secara harafiah pemaknaan asas tersebut tidak salah, namun tidak tepat. BW tetap berlaku meskipun telah ada WvK. Demikian juga Pasal 49 ayat (3) UUPA tetap berlaku meskipun telah ada Undang-Undang Wakaf. Terdapat beberapa prinsip yang harus diperhatikan dalam penerapan asas lex specialis derogat legi generali: 1) ketentuanketentuan yang didapati dalam aturan hukum umum tetap berlaku, kecuali 
yang diatur khusus dalam aturan hukum khusus tersebut; 2) ketentuanketentuan lex specialis harus sederajat dengan ketentuan-ketentuan lex generalis (undang-undang dengan undang-undang); 3) ketentuan-ketentuan lex specialis harus berada dalam lingkungan hukum (rezim) yang sama dengan lex generalis (Bagir, 2004: 57-58).

UUPA memuat aturan yang bersifat umum, bahwa perwakafan tanah milik dilindungi dan diatur dengan peraturan pemerintah. Ketentuan wakaf tanah baik menurut UUPA dan Undang-Undang Wakaf adalah sederajat yaitu sama-sama dalam bentuk undang-undang. UUPA dan Undang-Undang Wakaf sama-sama termasuk dalam lingkungan hukum administrasi negara. Dengan demikian Pasal 49 ayat (3) UUPA tetap berlaku meskipun telah lahir Undang-Undang Wakaf.

Asas lex posterior derogat legi priori ini tepat untuk menyelesaikan ketegangan antara PP 28 Tahun 1977 tentang Pendaftaran Tanah Milik dengan PP 42 Tahun 2006 tentang Pelaksanaan Undang-Undang Wakaf. Aturan hukum yang lebih baru mengesampingkan atau meniadakan aturan hukum yang lama. Asas lex posterior derogat legi priori mewajibkan menggunakan hukum yang baru. PP Pendaftaran Tanah Milik secara hukum tidak berlaku lagi dengan lahirnya PP Pelaksanaan Undang - Undang Wakaf. 


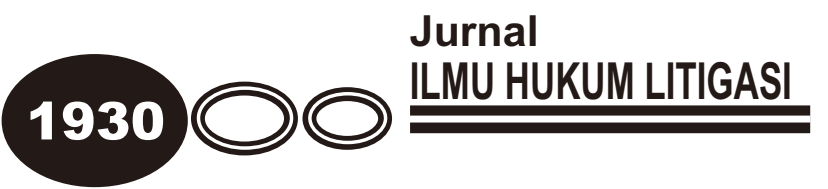

Dua syarat yang harus diperhatikan di dalam penerapan asas ini yaitu: a) aturan hukum yang baru harus sederajat atau lebih tinggi dari aturan hukum yang lama; b) aturan hukum baru dan lama mengatur aspek yang sama. Asas ini sudah terpenuhi untuk diterapkan terhadap kedua peraturan pemerintah dimaksud. Kedua peraturan pemerintah dimaksud secara substansi mengatur hal yang sama, yaitu pendaftaran wakaf termasuk wakaf tanah hak.

Ketidakberlakuan PP Pendaftaran Tanah Milik tidak harus dinyatakan di dalam peraturan yang baru. Dengan adanya asas lex posterior derogat legi priori, ketentuan yang mengatur pencabutan suatu peraturan perundangundangan sebenarnya tidak begitu penting. Asas ini bermaksud mencegah dualisme yang dapat menimbulkan ketidakpastian hukum. Secara hukum, ketentuan lama yang serupa tidak akan berlaku lagi pada saat aturan hukum baru mulai berlaku. Terdapat konsekuensi memuat klausula pencabutan secara tegas. Hal-hal yang tidak secara tegas dicantumkan sebagaimana telah dicabut dapat dianggap tetap berlaku. Keuntungan tidak menyantumkan klausula mencabut secara tegas, memungkinkan tetap memberlakukan ketentuan-ketentuan yang tidak cukup diatur dalam aturan hukum baru, tetapi didapati dalam aturan lama. PP Pelaksanaan Undang-Undang Wakaf tidak secara tegas mencabut PP Pendaftaran Tanah Milik. 
Posisi Peraturan Menteri Dalam Negeri No. 6 Tahun 1977 sebagai aturan Pelaksanaan PP Pendaftaran Tanah Milik adalah sama dengan PP Pendaftaran Tanah Milik. Artinya Peraturan Menteri Dalam Negeri tersebut secara otomatis tidak berlaku dengan lahirnya PP Pelaksanaan UndangUndang Wakaf, kecuali segala sesuatu yang belum diatur di dalam PP Pelaksanaan Undang-Undang Wakaf dan aturan pelaksanaannya. Keadaan ini sebagai konsekuensi dari ketentuan Undang-Undang Wakaf dan PP Pelaksanaan Undang-Undang Wakaf yang tidak secara tegas mencabut ketentuan di dalam UUPA dan PP Pendaftaran Tanah Milik. Ketentuan peralihan Undang-Undang Wakaf, mengatur bahwa dengan berlakunya Undang-Undang Wakaf maka wakaf yang dilakukan berdasarkan peraturan perundang-undangan yang berlaku sebelum diundangkannya undang-undang ini, dinyatakan sah sebagai wakaf menurut undang-undang ini, dan harus didaftarkan. Semua peraturan perundang-undangan yang mengatur mengenai perwakafan masih tetap berlaku sepanjang tidak bertentangan dan/atau belum diganti dengan peraturan yang baru. 


\section{2 \\ Jurnal \\ ILMU HUKUM LITIGASI}

\section{SIMPULAN DAN SARAN}

A. Simpulan

1. Perkembangan ketentuan wakaf di Indonesia telah sesuai dan sangat dipengaruhi oleh paham atau ajaran wakaf yang dianut oleh masyarakatnya. Telah terjadi perkembangan prinsip wakaf yang dianut di Indonesia, yaitu dari prinsip mengekalkan manfaat benda wakaf menjadikan prinsip tidak harus mengekalkan manfaat benda wakaf (wakaf dengan jangka waktu tertentu). Benda yang diwakafkan tetap kekal sesuai jangka waktu hak, dan dapat diperpanjang.

2. Ketentuan wakaf menurut UUPA tetap eksis bersama Undang-Undang Wakaf. Asas lex specialis derogat legi generalis berlaku di sini. Asas ini mengandung makna, bahwa aturan hukum yang khusus akan mengesampingkan aturan hukum yang umum. UUPA bersifat umum dan Undang-Undang Wakaf bersifat khusus. Sepanjang undang-undang khusus tidak meniadakan hukum yang umum, maka hukum yang umum tetap berlaku. PP Perwakafan Tanah Milik termasuk aturan pelaksanaan-nya tidak berlaku lagi dengan terbitnya PP Pelaksanaan Undang-Undang Wakaf. Berlaku-lah asas lex posterior derogat legi priori. Aturan hukum 
yang lebih baru mengesampingkan atau meniadakan aturan hukum yang lama dan mewajibkan menggunakan hukum yang baru.

B. Saran

Seyogianya wakaf tanah termasuk hak-hak atas tanah yang bersifat sementara, seperti Hak Bagi Hasil Tanah Pertanian, Hak Sewa untuk Bangunan, Hak Gadai Tanah Pertanian, dan Hak Sewa Tanah Pertanian. 


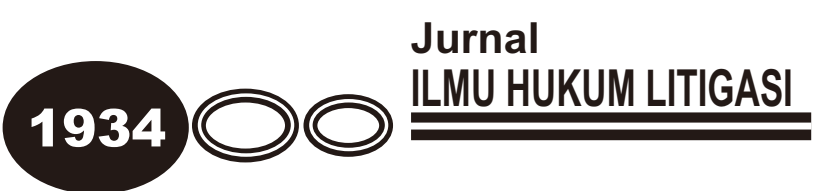

\section{DAFTAR PUSTAKA}

Bagir, Manan, 2004, Hukum Positif Indonesia, Suatu Kajian Teoritik, Yogyakarta, FH UII Press.

Boedi, Harsono, 2008, Hukum Agraria Indonesia: Sejarah Pembentukan UndangUndang Pokok Agraria, Isi dan Pelaksanaannya, Jakarta, Djambatan.

Bruggink, 1999, Refleksi Tentang Hukum, Penerjemah Areif Sidharta, Bandung, Citra Aditya Bakti.

Departemen Pendidikan Nasional, 2001, Kamus Besar Bahasa Indonesia, Edisi Ketiga, Jakarta, Balai Pustaka.

Kelsen, Hans, 2010, Teori Hukum Murni, Dasar-Dasar Ilmu Hukum Normatif (Pure Theory of Law), Penerjemah Raisul Muttaqien, Bandung, Nusa Media. ,2010, Teori Umum tentang Hukum dan Negara (General Theory of

Law and State) Penerjemah Raisul Muttaqien, Bandung, Nusa Media.

Maria, Farida Indrati S., 2007, IImu Perundang-Undangan, Jenis, Fungsi, dan Materi Muatan, Yogyakarta, Kanisius.

Parlindungan, AP, 2008, Berakhirnya Hak-Hak Atas Tanah Menurut Sistem UUPA, Bandung, Mandar Maju.

Satjipto, Rahardjo, 2006, IImu Hukum. Cet. ke 6, Bandung, Citra Adhitya Bahkti.

Sudikno, Mertokusumo, 2011, Teori Hukum, Yogyakarta, Universitas Adma Jaya Yogyakarta. 
Susi, Dwi Harjanti (ed.), 2011, Negara Hukum yang Berkeadilan, Kumpulan Pemikiran dalam Rangka Purnabakti Prof. Dr. H. Bagir Manan, S.H., M.CL. Bandung, PSKN FH UNPAD.

Yulia, Qamariyanti, 2004, Pengelolaan Harta Trust dan Wakaf, Bandung, Citra Aditya Bakti.

\section{MAKALAH}

Nur, Kholis, Wakaf Dan Upaya Memberdayakan Potensinya, Secara Produktif Di Indonesia, Disampaikan dalam Diskusi Ilmiah Terbatas “Hukum Islam di Indonesia", Yang Diselenggarakan oleh Program Pascasarjana FIAI Doktor Hukum Islam di Kampus Magister Studi Islam, Yogyakarta, Tgl 29 Juli 2009.

\section{WEBSITE}

Cholil, Nafis, Wakil Sekretaris Badan Wakaf Indonesia, "rethinking fiqihwakaf",http://bwi.or.id/index.php?option=com_content\&view= article \&id $=751 \% 3$ Arethinking-fiqih-wakaf\&catid, diunduh pada Kamis 4 Okt 2012, jam 11.30 wib. 


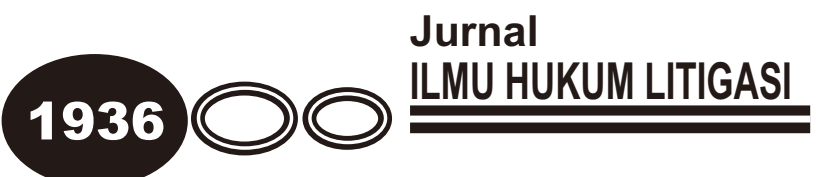

\section{PERATURAN PERUNDANGAN}

Undang-Undang No. 5 Tahun 1960 tentang Peraturan Dasar Pokok-Pokok Agraria.

Undang-Undang No. 41 Tahun 2004 tentang Wakaf.

Peraturan Pemerintah No. 28 tahun 1977 tentang Perwakafan Tanah Milik.

Peraturan Pemerintah No. 42 Tahun 2006 tentang Pelaksanaan Undang-Undang Wakaf.

Peraturan Menteri Dalam Negeri No. 6 Tahun 1977 tentang Tata Pendaftaran Tanah mengenai Perwakafan Tanah Milik.

Rancangan Undang-Undang tentang Pertanahan (draft tanggal 27 Maret 2013). 